\title{
CLINICOPATHOLOGICAL CORRELATION OF ASCITES WITH SPECIAL REFERENCE TO SERUM ASCITIC FLUID ALBUMIN CONCENTRATION GRADIENT (SAAG)- A STUDY IN A TERTIARY CARE CENTRE OF GAJRAULA, UTTAR PRADESH
}

\author{
Vinay Sharma1, Rachna Sharma², Sushil Sharma³, Neetu Goyal ${ }^{4}$ \\ ${ }^{1}$ Assistant Professor, Department of Pathology, Venkateshwara Institute of Medical Sciences, Gajraula, Uttar Pradesh, India. \\ ${ }^{2}$ Assistant Professor, Department of Pathology, SMMH, Medical College, Saharanpur, Uttar Pradesh, India. \\ ${ }_{3}^{3}$ Associate Professor, Department of Physiology, Venkateshwara Institute of Medical Sciences, Gajraula, Uttar Pradesh, India. \\ ${ }_{4}^{4}$ Associate Professor, Department of Pathology, SMMH, Medical College, Saharanpur, Uttar Pradesh, India.
}

\section{ABSTRACT}

\section{BACKGROUND}

Ascites is defined as collection of excessive fluid in peritoneal cavity. Normally there is little fluid between the visceral and parietal layers of peritoneum. A slight increase in normal volume of peritoneal fluid occurs in hepatic disease, cardiac disease and malignancies of pelvic and abdominal organs. The earlier approach in differential diagnosis constituted, separation of fluids on the basis of protein concentration in the ascitic fluid; defining transudate if protein levels are $<2.5 \mathrm{gm} / \mathrm{dl}$ and exudates if above that. Ascitic fluid protein estimation has long been used to divide ascitic fluid into exudates and transudate. Serum Ascitic Fluid Albumin Concentration Gradient (SAAG) has been reported to provide differentiation between portal hypertension related and non-related ascites. Therefore, the present study was undertaken to evaluate the role of serum-ascitic fluid-albumin-concentration gradient for the immediate etiologic diagnosis of ascites in order to simplify ascitic fluid analysis.

\section{METHODS}

This is a descriptive study. We studied 140 cases of ascites over a period of one year from Feb. 2018 to Feb. 2019. Samples for this study were collected from various outpatients and inpatients admitted in Medicine and Surgical Wards.

\section{RESULTS}

This study was conducted in the Department of Pathology, Venkateshwara Institute of Medical Sciences, Gajraula, Uttar Pradesh, India, taking into account 140 cases of ascites. Transudative ascites was found in $84.3 \%$ cases and the remaining $15.7 \%$ cases had exudative ascites. The commonest cause of transudative ascites was liver cirrhosis in $65 \%$ cases, followed by congestive cardiac failure in $8.6 \%$ cases, nephrotic syndrome in $6.4 \%$ cases and anaemia hypoproteinaemia in $4.3 \%$ cases. The cause of exudative ascites was tuberculosis in $10 \%$ cases and malignancy in $5.7 \%$ cases. Ascitic fluid total protein concentration was $<3$ gm/dl in all the cases of liver cirrhosis, congestive heart failure, nephrotic syndrome and anaemia-hypoproteinaemia; while in cases of tuberculous and malignant ascites it was $>3 \mathrm{gm} / \mathrm{dl}$. The highest protein concentration in ascites was $5.8 \mathrm{gm} / \mathrm{dl}$ found in a case of malignant ascites.

\section{CONCLUSIONS}

Serum Ascitic fluid albumin gradient is a better parameter for classification of cases of ascites than total protein concentration.

HOW TO CITE THIS ARTICLE: Sharma V, Sharma R, Sharma S, et al. Clinicopathological correlation of ascites with special reference to serum- ascitic fluid- albumin concentration- gradient (SAAG)- a study in a tertiary care centre of Gajraula, Uttar Pradesh. J. Evolution Med. Dent. Sci. 2019;8(18):1479-1484, DOI: 10.14260/jemds/2019/329

\section{BACKGROUND}

Ascites is defined as collection of excessive fluid in peritoneal cavity, normally there is little fluid between the visceral and parietal layers of peritoneum. A slight increase in normal volume of peritoneal fluid occurs in hepatic disease, cardiac disease and malignancies of pelvic and abdominal organs.

Ascites is a common clinical condition which may occur as part and parcel of anasarca or alone. It poses diagnostic problems to clinicians when it presents as ascites alone.

The earlier approach in differential diagnosis constituted separation of fluids on the basis of protein concentrations in

'Financial or Other Competing Interest': None.

Submission 14-03-2019, Peer Review 20-04-2019,

Acceptance 26-04-2019, Published 06-05-2019.

Corresponding Author:

Dr. Rachna Sharma,

W/o. Dr. Vinay Sharma,

\#185, Pawan Vihar, Jain College Road,

$4^{\text {th }}$ Lane from Ashram Riti Vidhyalaya,

Saharanpur-247001, Uttar Pradesh, India.

E-mail: rachnasharmasre@gmail.com

DOI: $10.14260 /$ jemds $/ 2019 / 329$

\section{(c) $($ ) $९$}

the ascitic fluid; defining transudate if protein levels are $<2.5$ $\mathrm{gm} / \mathrm{dl}$. And exudate if above that.

The differential diagnosis remains a problem in clinical practice. A complete separation between malignant and nonmalignant ascites has not always been possible. Ascitic fluid protein estimation has long been used to divide ascitic fluid into exudates and transudate. However, protein may be $>3$ $\mathrm{gm} / \mathrm{dl}$ in up to $15-20 \%$ cases of cirrhosis which conventionally are supposed to produce transudative ascites.

Other parameters like lactic dehydrogenase, $\mathrm{pH}$, Cell count have been tried but none of them have proved to be satisfactory. Recently Serum ascitic fluid albumin concentration gradient has been reported to provide differentiation between portal hypertension related and nonrelated ascites. The present study was undertaken to evaluate the role of serum-ascitic fluid-albumin concentration gradient for the immediate etiologic diagnosis of ascites in order to simplify ascitic fluid analysis.

\section{Aims and Objectives}

1. To evaluate e patients of ascites as per their clinical presentation.

2. To ascertain cytology and biochemistry of ascitic fluid. 
3. To enumerate cases of ascites as per their aetiology.

4. To find out Correlation of Cytological and biochemical finding with their clinical diagnosis.

5. To find out if ascitic fluid study alone can be regarded as a diagnostic parameter to find out its aetiology.

\section{METHODS}

\section{Study Design}

The present descriptive study was undertaken at Department of Pathology of a tertiary care centre, Gajraula, conducted over a period of one year from Feb. 2018 to Feb. 2019.

\section{Sampling Technique \\ Purposive sampling}

\section{Study Population}

A total of 140 cases of body effusions were included in the present study. Sample size was taken based on the convenience of the study. Samples for this study were collected from various outpatients and inpatients admitted in Medicine and Surgical wards of our Institution.

\section{Criteria for Selection of Patients}

All the patients presenting with ascites were taken into account. As per their clinical presentation, examination and investigations patients were categorised into following groups:

\section{Cirrhosis}

In this Group the patients, along with clinical evidence of cirrhosis, also had USG findings and/or raised SGOT, SGPT levels suggestive of alcoholic cirrhosis.

\section{Nephrotic Syndrome}

These patients presented with facial puffiness, lid oedema \& albuminuria. Few had evidence of renal failure in the form of raised Serum creatinine and blood urea levels.

\section{Congestive Cardiac Failure}

It was a clinical diagnosis in most cases with supportive investigations like ECG indicating the root cause of congestive cardiac failure.

\section{Anaemia-Hypoproteinaemia}

The diagnosis was clinical supported by low serum protein levels.

\section{Tuberculosis}

The clinical presentation was supported by raised ESR, H/o treatment with antituberculous drugs in past, evidence of tuberculosis elsewhere in the body, (i.e. cavity on chest - XRay or sputum positive for AFB) and turbid ascitic fluid with high protein levels.

\section{Malignancy}

These were the patients who along with their clinical presentation either showed malignant cells on ascitic fluid examination or evidence of malignancy on histopathology or on FNAC.
Ascitic fluid of all the patients were subjected to biochemical examination and cytology-

\section{(A) Biochemistry:}

The parameters studied were total protein, serum ascitic fluid albumin concentration gradient.

1. Ascitic fluid total protein concentration was estimated by using biuret method.

2. Ascitic fluid and serum albumin concentration was estimated by using Autopak albumin kits from Ames which use Bromo-cresol green (BCG) method. The readings were taken on autoanalyser.

\section{(B) Cytology-}

I. Routine wet film examination using improved Neubauer's Chamber was done using the methylene blue stain. Total nucleated cells/cubic mm were counted, and their differential count was also done.

II. Haematoxylin and eosin stain were used to assess the cytological features on smears made from ascitic fluid after centrifuging it for 10 minutes at $1500 \mathrm{rpm}$.

\section{Technique}

Ascitic fluid total protein estimation was carried out by Biuret Method-

\section{(A) Method-}

1. $5.9 \mathrm{ml}$ of normal saline and $6.0 \mathrm{ml}$ of Biuret was taken in two tubes (i.e. T \& S).

2. In tube (T) $0.1 \mathrm{ml}$ of sample was added.

3. In tube (S) $0.1 \mathrm{ml}$ of standard was added.

4. These were mixed well and incubated at $37^{\circ} \mathrm{C}$ for 10 minutes.

5. After incubation they were read for optical density on green filter $(540 \mathrm{~nm})$

6. Total proteins were calculated by following formula:

$$
\begin{aligned}
& \mathrm{T}_{\mathrm{p}}=\mathrm{T} / \mathrm{S} \times 6 \text { gm } \% \\
& \mathrm{~T} \rightarrow \text { Test } \\
& \mathrm{S} \rightarrow \text { Standard }
\end{aligned}
$$

7. Standard solution of albumin contained $100 \mathrm{mg} / \mathrm{dl}$.

Ascitic fluid and serum albumin concentration was estimated by using Autopak albumin kits from Ames which use Bromo Cresol Green (BCG) method.

\section{Principle}

Albumin in buffered solution reacts with anionic Bromocresol green (BCG) with a dye binding reaction to give a proportionate green colour which is measured at $628 \mathrm{~nm}$ The final colour is stable for 10 minutes.

\section{(B) Method-}

1. Sample was centrifuged at $1500 \mathrm{rpm}$ for 10 minutes.

2. Supernatant was discarded and smears were made from sediment.

3. Smears were fixed in (1:1) Ether alcohol for 30 minutes.

4. It was stained with Haematoxylin for 4 minutes.

5. It was differentiated with $1 \%$ Acid Alcohol.

6. It was put in running tap water for 5 minutes. 
7. Now it was counter stained with eosin for $1 \frac{1 / 2}{2}$ minutes.

8. It was again washed in running tap water.
9. It was blotted thrice and dehydrated in absolute alcohol for 1-2 minutes.

10. Blotted again and dipped in xylene.

11. It was blotted again and mounted in DPX.

RESULTS

\begin{tabular}{|c|c|c|c|}
\hline Sl. No. & Aetiology & No. of cases & Percentage (\%) \\
\hline 1 & Liver cirrhosis & 91 & 65 \\
\hline 2 & Tuberculous peritonitis & 14 & 10 \\
\hline 3 & CCF & 12 & 8.6 \\
\hline 4 & Nephrotic syndrome & 9 & 6.4 \\
\hline 5 & Anaemia hypoproteinaemia & 6 & 4.3 \\
\hline 6 & Malignant ascites & 8 & 5.7 \\
\hline \multicolumn{2}{|c|}{ Table 1. 140 Cases of Ascites of Different Aetiology } \\
\hline
\end{tabular}

\begin{tabular}{|c|c|c|c|c|c|c|}
\hline $\begin{array}{c}\text { Age Groups } \\
\text { Years }\end{array}$ & Liver Cirrhosis & $\begin{array}{c}\text { Tuberculous } \\
\text { Peritonitis }\end{array}$ & CCF & $\begin{array}{c}\text { Nephrotic } \\
\text { Syndrome }\end{array}$ & $\begin{array}{c}\text { Anaemia } \\
\text { Hypoproteinaemia }\end{array}$ & $\begin{array}{c}\text { Malignant } \\
\text { Ascites }\end{array}$ \\
\hline $0-10$ & 4 & - & 1 & 4 & 2 & - \\
\hline $11-20$ & 6 & 2 & 3 & - & 1 & - \\
\hline $21-30$ & 19 & 1 & 4 & 2 & - & - \\
\hline $31-40$ & 33 & 7 & 2 & - & 2 & 1 \\
\hline $41-50$ & 17 & 3 & 2 & 3 & - & 4 \\
\hline$>50$ & 12 & 1 & - & - & - & 3 \\
\hline Total Cases & $\mathbf{9 1}$ & $\mathbf{1 4}$ & $\mathbf{1 2}$ & $\mathbf{9}$ & $\mathbf{6}$ & $\mathbf{8}$ \\
\hline
\end{tabular}

Table 2. Age-Wise Distribution of Cases Analysed

As is evident from the table, ascites was found to be a common presentation in $3^{\text {rd }}$ and $4^{\text {th }}$ decade, liver cirrhosis and tuberculosis being common cause; Malignancy is a cause of ascites was found commonly in $4^{\text {th }}$ and $5^{\text {th }}$ decade (In $87.5 \%$ cases).

\begin{tabular}{|c|c|c|c|c|c|c|}
\hline Sl. No. & Aetiology & Total No. of Cases & \multicolumn{2}{c|}{ Male No. \% Age } & \multicolumn{2}{c|}{ Female No. \% Age } \\
\hline 1 & Liver cirrhosis & 91 & 70 & 76.9 & 21 & 23.1 \\
\hline 2 & Tuberculous peritonitis & 14 & 5 & 35.7 & 9 & 64.3 \\
\hline 3 & CCF & 12 & 3 & 25.0 & 9 & 75.0 \\
\hline 4 & Nephrotic syndrome & 9 & 6 & 66.7 & 3 & 33.3 \\
\hline 5 & Anaemia hypoproteinaemia & 6 & 2 & 33.3 & 4 & 66.7 \\
\hline 6 & Malignant ascites & 8 & 5 & 62.5 & 3 & 37.5 \\
\hline
\end{tabular}

Table 3. Sex-Wise Distribution of Ascites of Various Aetiology

Table 3 shows liver cirrhosis (76.9\%), Nephrotic Syndrome (66.7\%) and Malignancy (62.5\%) as a cause of ascites were commonly seen in males. In females, tuberculosis (64.3\%), CCF (75\%) and anaemia (66.7\%) were more common causes.

\begin{tabular}{|c|c|c|c|c|c|c|}
\hline Gross Appearance & Liver Cirrhosis & $\begin{array}{c}\text { Tuberculous } \\
\text { Peritonitis }\end{array}$ & CCF & $\begin{array}{c}\text { Nephrotic } \\
\text { Syndrome }\end{array}$ & $\begin{array}{c}\text { Anaemia } \\
\text { Hypoproteinaemia }\end{array}$ & $\begin{array}{c}\text { Malignant } \\
\text { Ascites }\end{array}$ \\
\hline Yellow & $85.7 \%$ & - & $100 \%$ & $100 \%$ & $100 \%$ & - \\
\hline Straw colour & $13.2 \%$ & - & - & - & - & - \\
\hline Turbid & $1.1 \%$ & $92.28 \%$ & - & - & - & 62.5 \\
\hline Haemorrhagic & - & $7.2 \%$ & - & - & - & 25.0 \\
\hline
\end{tabular}

Table 4. Gross Appearance of Ascitic Fluid in 140 Cases of Ascites of Various Aetiology

Table 4 shows in maximum cases of tuberculosis (92.8\%) and malignant Ascites, fluid was turbid, while all the cases of cirrhosis, CCF, nephrotic syndrome and anaemia hypoproteinaemia had clear yellow/straw coloured fluid. Haemorrhagic ascitic fluid was found in $7.2 \%$ cases of tuberculous peritonitis and $25 \%$ cases of malignant ascites.

\begin{tabular}{|c|c|c|c|}
\hline Aetiology & $<\mathbf{1 0 0}$ cells/cumm & $\mathbf{1 0 0 - 5 0 0}$ cells/cumm & $>\mathbf{5 0 0}$ cells/cumm \\
\hline Liver cirrhosis & $84(92.3 \%)$ & $6(6.6 \%)$ & $1(1.1 \%)$ \\
\hline Tuberculous peritonitis & $6(42.8 \%)$ & $8(57.20 \%)$ & - \\
\hline CCF & $12(100 \%)$ & - & - \\
\hline Nephrotic syndrome & $9(100 \%)$ & - & - \\
\hline Anaemia hypoproteinaemia & $6(100 \%)$ & $3(37.5 \%)$ & - \\
\hline Malignant ascites & $5(62.5 \%)$ & \multicolumn{2}{|c|}{}
\end{tabular}

Table 5. Leukocyte Count in Ascitic Fluid of Different Aetiologies (Cases in \%)

Table 5 shows Nucleated Cells > 100/cumm were seen in $57.2 \%$ cases of tuberculosis, $37.5 \%$ cases of malignant ascites and $7.7 \%$ cases of cirrhotic ascites; in rest of the cases the leukocyte count was $<100$ cells/cumm. 


\begin{tabular}{|c|c|c|}
\hline \multirow[b]{2}{*}{$\begin{array}{l}\text { Total No. of } \\
\text { Cases } 8\end{array}$} & $\begin{array}{l}\text { Positive for malignancy on cytology } 4 \\
\qquad(50 \%) \text { cases }\end{array}$ & $\begin{array}{l}\text { Histopathologically proven bronchoalveolar carcinoma with transcoelomic } \\
\text { spread to pleural and peritoneal cavity in } 1(12.5 \%) \text { cases. Origin of rest of } \\
\qquad 3(37.5 \%) \text { cases unknown. }\end{array}$ \\
\hline & $\begin{array}{l}\text { Negative for malignancy on cytology } 4 \\
(50 \%) \text { cases }\end{array}$ & $\begin{array}{c}\text { On histopathology, } 1(12.5 \%) \text { case was found to be granulosa cell tumour. } \\
\text { Rest - } 2(25 \%) 3(37.5 \%) \text { cases of cases on adenocarcinoma FNAC. } \\
-1(12.5 \%) \text { secondaries in liver } \\
\text { Histopathological confirmation of last } 3 \text { cases was not done. }\end{array}$ \\
\hline
\end{tabular}

\section{Table 6. Cytology of Malignant Ascites}

Table 6 shows out of 8 cases only 4 (50\%) were positive for malignant cells on ascitic fluid cytology. Origin of only two tumours (1 cytologically positive and 1 negative for malignant cells on ascitic fluid cytology) was confirmed on histopathology.

\begin{tabular}{|c|c|c|c|c|c|}
\hline Aetiology & $\begin{array}{l}\text { Ascitic Fluid Total } \\
\text { Protein (gm/dl.) }\end{array}$ & \begin{tabular}{|c|} 
Mean Total \\
Protein (gm/dl.) \\
\end{tabular} & $\begin{array}{c}\text { SAAG } \\
\text { (gm/dl.) }\end{array}$ & $\begin{array}{l}\text { Mean } \\
\text { SAAG }\end{array}$ & \\
\hline Liver cirrhosis & $1.1-2.9$ & $1.83 \pm 0.90$ & $1.2-2.0$ & $1.55 \pm 0.22$ & \multirow{6}{*}{$\begin{array}{l}\mathrm{p} \text { Value }<0.0001 \\
\text { highly significant }\end{array}$} \\
\hline Tuberculous peritonitis & $3.2-5.6$ & $3.56 \pm 0.92$ & $0.8-1.3$ & $1.17 \pm 0.19$ & \\
\hline CCF & $0.7-2.3$ & $1.51 \pm 0.43$ & $1.24-2.2$ & $1.64 \pm 0.29$ & \\
\hline Nephrotic syndrome & $1.0-1.4$ & $1.27 \pm 0.27$ & $1.3-2.0$ & $1.57 \pm 0.23$ & \\
\hline Anaemia hypoproteinaemia & $0.9-1.3$ & $1.16 \pm 0.14$ & $1.4-1.9$ & $1.7 \pm 1.17$ & \\
\hline Malignant ascites & $3.2-5.8$ & $3.95 \pm 2.24$ & $0.8-1.2$ & $0.98 \pm 0.46$ & \\
\hline
\end{tabular}

\begin{tabular}{|c|c|c|}
\hline Authors & Mean Ascitic Fluid Total Protein gm/dl & Mean Total SAAG gm/dl. \\
\hline Pare P.et al 1983(1) & $1.66 \pm 1.20$ & $1.85 \pm 1.20$ \\
\hline Mauer K. et al 1986(2) & $1.61 \pm 0.95$ & $1.60 \pm 0.61$ \\
\hline Colli A. et al 1986(3) & $1.83 \pm 1.52$ & $2.00 \pm 1.01$ \\
\hline Albillos A. et al 1990(4) & $1.50 \pm 0.84$ & $2.05 \pm 0.45$ \\
\hline Garg R. et al 1993(5) & - & $2.78 \pm 0.79$ \\
\hline Present Study & $1.83 \pm 0.90$ & $1.55 \pm 0.52$ \\
\hline \multicolumn{2}{|c|}{ Table 8. Showing Comparison of Biochemical Parameters Between Previous Studies and Present One } \\
\hline
\end{tabular}

\begin{tabular}{|c|c|}
\hline Authors & Mean SAAG (gm/dl) \\
\hline Pare P. et al 1983 & $0.72 \pm 0.30$ \\
\hline Colli A. et al 1986 & $1.25 \pm 0.72$ \\
\hline Albillos A. et al 1990 & $2.24 \pm 1.20$ \\
\hline Garg R. et al 1993 & $0.94 \pm 0.51$ \\
\hline Present Study & $0.98 \pm 0.46$ \\
\hline \multicolumn{2}{|c|}{ Table 9. Showing Comparison of SAAG Between Previous Studies and Present One } \\
\hline $\begin{array}{l}\text { In the above table, Fisher Exact Test was applied, and p value was < } 0.0001 \text { which is highly significant. (Fisher Exact Test is test of } \\
\text { significance for categorical). }\end{array}$ \\
\hline
\end{tabular}

\section{Statistical Analysis}

The data was entered in MS-Excel and analysed using EpiInfo 7 Software. Frequencies and means of findings were calculated and appropriate test of significance (Fisher Exact Test) were applied.

The present study comprised of one hundred forty (140) cases of different body effusions over a period of one year from Feb. 2018 to Feb. 2019, received in the Department of Pathology, Venkateshwara Institute of Medical sciences, Gajraula, collected from various outpatients and inpatients admitted in Medicine and Surgical wards of this Medical College, Hospital.

\section{RESULTS}

Serum ascitic fluid albumin concentration gradient was found to be $\geq 1.2 \mathrm{gm} / \mathrm{dl}$. in all the cases of non-malignant ascites while it was $\leq 1.2 \mathrm{gm} / \mathrm{dl}$ in cases of malignant ascites.

As per Table 7 ascitic fluid proteins were found to be much higher in tuberculous and malignant ascites as compared to total protein levels, found in cases of ascites of other aetiologies.

SAAG (Serum Ascitic Fluid Albumin Gradient) was found to be less than $1.2 \mathrm{gm} / \mathrm{dl}$ in cases of malignant ascites while albumin gradient was $\geq 1.2 \mathrm{gm} / \mathrm{dl}$ in ascites due to nonmalignant cause.

\section{DISCUSSION}

In etiological classification of ascites is quite often a problem, especially if the clinical picture is not clear. Amongst the various aetiologies, transudative ascites is caused by livercirrhosis, congestive heart failure, anaemia hypoproteinaemia and nephrotic syndrome. Exudatives ascites is seen with tuberculosis and malignancies commonly.

Although the entity is commonly seen in $2^{\text {nd }}$ and $3^{\text {rd }}$ decade; it can occur at any age group.

Jain S.C. et al 1966 (6) reported maximum number (66\%) of cases of ascites in $3^{\text {rd }}$ and $4^{\text {th }}$ decade; while we found most $(52.8 \%)$ of our cases in $4^{\text {th }}$ and $5^{\text {th }}$ decade. The reason of this difference was that the biggest pool of patients (78\%) in their study was constituted by tuberculosis (42\%) and cirrhosis (36\%). They had most of their cases of tuberculosis in $3^{\text {rd }}$ decade and those of cirrhosis in $4^{\text {th }}$ decade; while in our study most cases included were of cirrhosis (65\%); $55 \%$ of which were found in $4^{\text {th }}$ and $5^{\text {th }}$ decade.

Nath et al 1966(7) reported distribution of cases of ascites in male and female as $70 \%$ and $30 \%$ respectively. Our findings that is the occurrence of $65 \%$ male patients and $35 \%$ 
female patients in ascites is in accordance with Nath et al 1966.

Mehrotra M.P. and Mangal R.P. 1964(8) in their study found male and female ratio almost as 1:1. The reason for this finding was that their main patient pool consisted of cases of Cirrhosis (50\%) and tuberculosis (30\%), while cirrhosis was common in males, females predominance (80\%) was seen in cases of tuberculosis.

Jain S.C. et al 1966, however had included a greater number of cases of tuberculosis (42\%), than cirrhosis (36\%). The incidence of tuberculosis was found to be higher in females and hence the male to female ratio of 2:3 was found.

In our observations, we found the incidence of cirrhosis in ascites as $65 \%$, our findings are comparable with findings of Nath et al 1966 (58.6\%) and those of Mehrotra M.P. \& Mangal R.P. 1964 (50\%).

The incidence of tuberculosis in ascites in present study (10\%) was found to be lower than the previous studies that is $30 \%$ in study by Mehrotra M. P. \& R. P. Mangal 1964 and 42\% in study by Jain S.C. et al 1966 . The reason for this can be the awareness of entity called tuberculosis in patients, early diagnosis and early treatment.

Incidence of CCF in ascites in our study was found to be $8.6 \%$ which is similar with finding of Mehrotra M.P. \& Mangal R.P. 1964 (6\%).

Sikka et al $1967(9)$ reported as incidence of $21.7 \%$. The reason for the higher incidence was not explained by the author. The incidence of nephrotic syndrome (6.4\%), anaemia - hypoproteinaemia (4.3\%) and malignant ascites (5.7\%) was comparable with reports from previous workers.

Tito L.et al $1988{ }^{(10)}$ reported $56.7 \%$ cases in $3^{\text {rd }}$ and $4^{\text {th }}$ decade; while Ljubi Ci. C. N. et al 1993(11) found 59.2\% cases of cirrhosis in the same decades. Our finding (57.1\% of cases) in these two decades is similar) Tito L.et al 1988 and Ljubi Ci. C. N. et al 1993.

Cirrhosis as a cause of ascites is more common in males as compared to females. The most probable reason being more incidence of alcohol consumption by males as compared to females and alcoholic cirrhosis is the commonest form of cirrhosis in males.

We found a male to female ratio of about $3: 1$ which is in accordance with findings by Ljubi Ci.C.N. et al 1993, Nath et al 1966.

Mean ascitic fluid total protein concentration in our study was $1.83 \pm 0.90 \mathrm{gm} / \mathrm{dl}$ which is in accordance with the findings of previous work.

Mean serum-ascitic fluid albumin concentration gradient in our study was $1.55 \pm 0.52 \mathrm{gm} / \mathrm{dl}$ which is also similar to the findings of previous work. The gradient has been shown to correlate directly with portal pressure. The patients with a gradient of $1.1 \mathrm{gm} / \mathrm{dl}$ or more have been shown to have portal hypertension while those with a gradient less than 1.1 gm/dl do not have the disorder (Hoefs J.C., 1983.(12))

Pare P. et al 1983 reported ascitic fluid total protein levels of $3.4 \mathrm{gm} / \mathrm{dl}$. In the only case they studied; while Albillos A. et al 1990 found an ascitic fluid total protein concentration of $1.0 \mathrm{gm} / \mathrm{dl}$ in the only case they included in their study.

We found ascitic fluid total protein concentration between 1.0 and $1.4 \mathrm{gm} / \mathrm{dl}$ which is in accordance with findings of Albillos A. et al 1990.

Pare P. et al 1983 reported an Albumin gradient of 0.8 $\mathrm{gm} / \mathrm{dl}$ in their case, while Albillos A.et al 1990 found it to be
$1.3 \mathrm{gm} / \mathrm{dl}$. The reason for narrow albumin gradient is said to be due to absence of increase portal pressure in the genesis of ascites in nephrotic syndrome Pare P. et al 1983.

We found a serum ascitic fluid albumin concentration gradient between 1.3 and $2.0 \mathrm{gm} / \mathrm{dl}$ which correlates with findings of Albillos A.et al 1990.

Sikka et al 1967 reported CCF as a cause of ascites in $21.7 \%$ cases.

We found CCF as a cause of ascites in $8.6 \%$ cases.

Pare P. et al 1983 reported an ascitic fluid total protein level of $2.4 \mathrm{gm} / \mathrm{dl}$ in the only case they studied. Albillos A. et al 1990 reported ascitic fluid total protein levels of 5.0, 3.6, 4.0 and $3.6 \mathrm{gm} / \mathrm{dl}$ in the four cases they included in their study.

We found Ascitic fluid total protein levels between 0.7 and $2.3 \mathrm{gm} / \mathrm{dl}$; the mean value being $1.51 \pm 0.43 \mathrm{gm} / \mathrm{dl}$.

The high ascitic fluid protein levels found in study by Albillos A. et al 1990 can be explained by the fact that in CCF pronounced right ventricular pulsations are preferentially transmitted to hepatic vein; which enters the inferior vena cava below right atrium resulting in liver congestion and ascites Cronin C.C. et al 1996.(13)

Pare P. et al 1983, reported SAAG value as $1.7 \mathrm{gm} / \mathrm{dl}$ in the only case they studied.

Albillos A. et al 1990 reported SAAG values as 1.2, 2.1, 1.3 and $1.8 \mathrm{gm} / \mathrm{dl}$ in the four cases they included in their study.

We found SAAG value between 1.2 and $2.2 \mathrm{gm} / \mathrm{dl}$ the mean value being $1.64 \pm 0.29 \mathrm{gm} / \mathrm{dl}$. These are similar to the values reported by Albillos A. et al 1990.

Mehrotra M.P. and Mangal R.P. 1964 reported tuberculosis as a cause of ascites in $30 \%$ cases while Jain S.C. et al 1966 and Mehrotra et al 1972(14) reported as incidence of $42 \%$ and $28.2 \%$ respectively.

We found an incidence of $10 \%$ which is lower than the values quoted in previous works. The most probable reason for this decline in tuberculosis incidence is early detection and early treatment of cases.

According to our study total protein concentration is ascitic fluid $>3 \mathrm{gm} / \mathrm{dl}$ in all the cases of tuberculosis. Total protein levels may be as high as $7.5 \mathrm{gm} / \mathrm{dl}$ Singh et al 1969(15).

We found total protein concentration between 3.2 and 5.6 $\mathrm{gm} / \mathrm{dl}$. The highest protein concentration being $5.6 \mathrm{gm} / \mathrm{dl}$ in one case.

Albillos A. et al 1990 reported an albumin gradient of 0.7 and $0.8 \mathrm{gm} / \mathrm{dl}$ in the two cases they studied.

In our Study SAAG was $0.8-1.3 \mathrm{gm} / \mathrm{dl}$ a value close to reported by Albillos A. et al 1990.

Sood A. et al 1995(16) reported the mean SAAG in their study as $0.82 \pm 0.25$ which they found statistically insignificant $(\mathrm{P}<0.05)$ to differentiate tuberculous ascites from malignant ascites.

The mean SAAG was found to be $1.17 \pm 0.19 \mathrm{gm} / \mathrm{dl}$.

Metastasis to peritoneal cavity occurs in nearly $40 \%$ of all the serous cavity (Foot NC 1956(17), Murphy 1972(18) and Spieler et al 1985.(19)

As per reports by Sikka et al 1967 and Mehrotra et al 1972 malignancy accounts for 6-7\% of all the cases of ascites.

We found the malignancy as a cause of ascites in $5.7 \%$ of cases. Our finding is comparable with those of Mehrotra et al 1972 (6.2\%), Sikka et al 1967 (7.2\%) and Nath et al 1966 (8.57\%). 
Although Malignancies can occur at any age group, most commonly they are seen in older age group.

We found 7 (88.5\%) cases of malignant ascites in $4^{\text {th }}$ and $5^{\text {th }}$ decades.

Total protein levels in ascitic fluid in most of malignant cases are $>3$ gm/dl Mehrotra M. P. and Mangal R. P. 1964 and Nath et al 1966.

Pare P. et al 1983 reported the diagnostic accuracy of total protein levels in ascitic fluid $>2.5 \mathrm{gm} / \mathrm{dl}$ as $80 \%$ in differentiating malignant from non-malignant ascites.

Albillos A. et al 1990 reported total protein concentration in ascitic fluid $>3 \mathrm{gm} / \mathrm{dl}$ in $85 \%$ of the cases of malignant ascites.

Mauer K. et al 1986 reported comparatively low ascitic fluid protein concentration $(2.35 \pm 0.56 \mathrm{gm} / \mathrm{dl})$ in cases of malignant ascites with liver metastasis than those without liver metastasis $(3.80 \pm 0.65 \mathrm{gm} / \mathrm{dl})$.

We found ascitic fluid total protein concentration between 3.2 and $5.8 \mathrm{gm} / \mathrm{dl}$ with a mean value of $3.95 \pm 2.24$ $\mathrm{gm} / \mathrm{dl}$ which is comparable with previous studies.

Serum ascitic fluid albumin concentration gradient $<1.1$ $\mathrm{gm} / \mathrm{dl}$ is said to be a good indicator of malignancy.

We found the serum ascitic fluid albumin concentration gradient from 0.7 to $1.2 \mathrm{gm} / \mathrm{dl}$ with a mean value of $0.98 \pm$ 0.46 which closely correlates with findings of other works.

According to Pare P. et al 1983 malignant tumours cause effusions by increasing the permeability or blocking the lymphatics and not necessarily by blocking veins of vascular system. Therefore, when portal pressure is not increased, ascites formation occurs in the presence of oncotic gradient.

Since albumin is the main determinant of oncotic pressure, albumin concentration gradient can be used to document presence or absence of portal hypertension.

\section{CONCLUSIONS}

Ascitic fluid examination is an important diagnostic aid in etiological diagnosis of ascites.

Serum ascitic fluid albumin gradient (SAAG) is a better parameter for classifications of cases of ascites than total protein concentration.

However, SAAG does not change rapidly when ascitic fluid infection develops. So, neither it can replace cell count nor culture for the diagnosis of infection. Similarly, it cannot replace ascitic fluid cytology or culture for acid fast bacilli in confirmation of diagnosis of peritoneal carcinomatosis and tuberculosis respectively.

Ascitic fluid cytology though highly specific for malignant ascites is not very sensitive measure as we could find only $50 \%$ of our cases positive on cytology for malignant cells.

Thus, ascitic fluid cytology should be aided by estimation of SAAG to make the etiological diagnosis of ascites more accurate.

\section{REFERENCES}

[1] Pare P, Talbot J, Hoefs JC. Serum-ascites albumin concentration gradient: a physiological approach to the differential diagnosis of ascites. Gastroenterology 1983;85(2):240-4.

[2] Mauer K, Manzione NC. Usefulness of the Serum ascites albumin gradient in separating transudative from exudative ascites: another look. Diag Dis Sci 1988;33(10):1208-12.
[3] Colli A, Buccino G, Cocciolo M, et al. Diagnostic accuracy of fibronectin in the differential diagnosis of ascites. Cancer 1986;58(11):2489-93.

[4] Albillos A, Ciervas-Mons V, Millan I, et al. Ascitic fluid polymorphonuclear cell count and serum to ascitic albumin gradient in the diagnosis of bacterial peritonitis. Gastroenterology 1990;98(1):134-40.

[5] Garg R, Sood A, Arora S, et al. Ascitic fluid cholesterol in differential diagnosis of ascites. J Asso Phys India 1993;41(10):644-6.

[6] Jain SC, Misra SM, Misra NP, et al. Diagnostic value of ascitic fluid examination. J Asso Phys Ind 1966;14(1):59-69.

[7] Nath K, Mital HS, Mishra SD, et al. Diagnostic value of ascitic fluid examination. J Assoc Phys Ind 1968;16(12):991-6.

[8] Mehrotra MP, Mangal RP. Biochemical and cytological findings of ascitic fluid in different disorders - a preliminary report. J Asso Phys Ind 1964;12:53-61.

[9] Sikka KK, Nath K, Agarwal SN, et al. Study of serum proteins in health and in ascites of varying etiologies. J Asso Phys Ind 1967;15(12):591-4.

[10] Tito L, Rimola A, Gines P, et al. Recurrence of spontaneous bacterial peritonitis in cirrhosis: frequency \& predicative factors. Hepatology 1988;8(1):27-31.

[11] Ljubicić N, Bilić A, Babić $\mathrm{Z}$, et al. The significance of low levels of total proteins, albumin, globulins and compliment factors, in ascitic fluid and the development of spontaneous bacterial peritonitis in patients with liver cirrhosis. Lijec Vjesn 1992;114(912):213-5.

[12] Hoefs JC. Serum Protein concentration and portal pressure determine the ascitic fluid protein concentration in patients with Chronic liver disease. J Lab Clin Med 1983;102(2):260-73.

[13] Cronin CC, Duggan M. Ascitic fluid protein concentration. Lancet 1996;347(9003):772-3.

[14] Mehrotra. Etiological classification of ascites. Ind J Med Res 1972;60:1089-100.

[15] Singh MM, Bhargava AN, Jain KP. Tuberculous peritonitis. An evaluation of pathogenetic mechanisms, diagnostic procedures and therapeutic measures. N Engl J Med 1969;281(20):1091-4.

[16] Sood A, Garg R, Kumar R, et al. Ascitic fluid cholesterol level in malignant and tubercular ascites. J Asso Phys Ind 1995;43(11):745-7.

[17] Foot NC. The identification of neoplastic cells in serous effusions: critical analysis of smears from 2,029 persons. Am J Pathol 1956;32(5):961-77.

[18] Murphy WM, Ng AB. Determination of primary site by examination of cancer cells in body fluids. Am J Clin Pathol 1972;58(5):479-88.

[19] Spieler P, Gloor F. Identification of type and primary site of malignant cells by examination of exfoliated tumour cells in serous fluids. Comparison with diagnostic accuracy on small histologic biopsies. Acta Cytologica 1985;29(5):753-67. 